\title{
Does the invisible hand hold or lead? Market adjustment in an entrepreneurial economy
}

\author{
Randall G. Holcombe
}

(C) Springer Science + Business Media, Inc. 2006

\begin{abstract}
Adam Smith's "invisible hand" is one of the best-known phrases in economics, but its meaning is somewhat ambiguous. The invisible hand might be viewed as holding the economy close to equilibrium, yet Smith actually says that individuals are led by an invisible hand. Entrepreneurial forces lead an economy along a path that generates economic progress, and that path is determined by the disruptive forces of entrepreneurship. Rather than viewing an economy as tending toward an equilibrium, it is more accurate to view an economy as characterized by continuing progress, led by the invisible hand of entrepreneurial activity.
\end{abstract}

Keywords Entrepreneurship · Equilibrium · Growth · Invisible hand · Progress

JEL Code B53, D21, E32, O31

\section{Introduction}

The invisible hand — the phrase popularized by Adam Smith (1776) — is one of the best-known concepts in economics, but its meaning is somewhat ambiguous, as Holcombe (1999) notes. Taking an equilibrium approach to economic analysis, as is characteristic of twentieth century economics, the invisible hand is often characterized as the force that holds the economy close to equilibrium, and nudges it back whenever an equilibrium is disturbed. Yet a look at Smith's actual words suggests that this is not what he had in mind. Smith (1776: 423) said,

As every individual, therefore, endeavours as much as he can both to employ his capital in the support of domestic industry, and so to direct that industry that its produce may be of the greatest value; every individual necessarily labours to render the annual revenue of the society as great as he can. He generally, indeed, neither intends to promote the public interest, nor knows how much he is promoting it. By preferring the support of domestic to that of foreign industry, he intends only his own security; and by directing that industry in such a manner as its produce may be of the greatest value, he intends only his own gain, and he is in this, as in many other cases, led by an invisible hand to promote an end which was no part of his intention.

R. G. Holcombe $(\square)$

Department of Economics, Florida State University, Tallahassee, Florida 32306

e-mail: holcombe@garnet.acns.fsu.edu 
The final sentence of that quotation answers the question asked in the paper's title: Smith says that the invisible hand leads.

In the paragraph where Smith discusses the invisible hand, he is discussing how individuals employ their capital, and says they try to employ it in a way that maximizes the value of what it produces. As Smith describes it, the invisible hand leads people to look for ways to employ the resources under their control in a manner that maximizes the value those resources produce.

Twentieth century economics has focused on the properties of equilibrium, and in so doing has provided substantial insight into the equilibrating forces in an economy. But equilibrium models of the economy, like all models, are simplified depictions of reality. Even the most complex model depicts only a small part of what goes on in the real world. While equilibrium models shed light on some issues, they obscure others for the same reason that any model obscures some issues. Because models are a simplified depiction of reality, by necessity they cannot accurately convey relationships that are assumed away, or are depicted unrealistically, as Holcombe (1989) notes. For some purposes it is illuminating to depict an economy as tending toward an equilibrium, but for other purposes this equilibrium view of the economy obscures the workings of economic processes that are important to the overall operation of an economy, as Kohn (2004) insightfully explains.

This paper focuses on disruptions within an economy, and shows why an equilibrium approach mischaracterizes the nature of economic disruptions. Within an equilibrium framework, an economy tends toward equilibrium, and disruptive factors pull the economy away. Equilibrating forces then tend to pull it back. However, in reality an economy does not tend toward a unique equilibrium, but rather follows a path that is not unique, and more significantly, that is determined by those disruptions. ${ }^{1}$ Furthermore, disruptions are not aberrant forces in an economy, or "shocks" to an otherwise stable economy, but rather are a part of the ongoing process of economic progress. Entrepreneurial activity in an economy both determines that path and keeps the economy close to it. The paper begins by taking a critical look at the equilibrium framework within which most economic analysis takes place.

\section{What does equilibrium economics show?}

Equilibrium economics shows the properties of economic equilibrium. It shows where economic forces are tending to pull prices and quantities in markets at any particular point in time. In this context, a robust economy is one that rapidly returns to equilibrium if anything happens to disturb an existing equilibrium. In an equilibrium framework, an existing equilibrium can be disturbed by shifts in supply or demand which, Keynes (1936) argued, classical economics implied would be met with rapid adjustment by market forces, returning the economy to equilibrium. Keynes's own argument, in contrast, was that there were features of a modern monetary economy that kept that adjustment from happening. Keynesian macroeconomics is not unusual in focusing on the ability of an economy to adjust to disruptions, and to allocate resources efficiently in response to disequilibrating shocks. In two of the seminal works that define the modern paradigm in economics, Hicks (1939) and

\footnotetext{
${ }^{1}$ Arrow and Debreu (1954) prove that there is a unique and stable competitive equilibrium, which appears to contradict the claim in this sentence. However, that proof assumes a static and timeless economy. When time is added to such a model, it is apparent that the "unique" equilibrium the economy approaches at one point in time is different from the "unique" equilibrium it approaches at a different time. The question then becomes whether the path of equilibria over time is unique, and this paper argues below that it is not.
} 
Samuelson (1947) lay out a general equilibrium formulation of the economy and then add dynamic elements to show how economic forces can disrupt economic equilibria, and how and under what conditions economies can reequilibrate.

This equilibrium approach to analyzing the economy does not adequately capture all of the alternatives. In Smith's conception of economic activity, the economy does not adjust to a new equilibrium, but rather is continually led on a trajectory determined by the entrepreneurial innovations of the economy's participants. Smith (1776: 9) notes,

\begin{abstract}
But in consequence of the division of labour, the whole of every man's attention comes naturally to be directed towards some one very simple object. It is naturally to be expected, therefore, that some one or another of those who are employed in each particular branch of labour should soon find easier and readier methods of performing their own particular work, wherever the nature of it admits of such improvement. A great part of the machines made use of in those manufactures in which labour is most subdivided, were originally the invention of common workmen, who, being each of them employed in some very simple operation, naturally turned their thoughts towards finding out easier and readier methods of performing it. Whoever has been much accustomed to visit such manufactures, must frequently have been shewn very pretty machines, which were the invention of such workmen, in order to facilitate and quicken their own particular part of the work.
\end{abstract}

The activity Smith describes is that of workers looking for more productive ways to employ their capital and the capital of their employers. Seen in the context of equilibrium economics, the result of this activity is not to pull the economy toward an equilibrium but rather to lead it on a path toward greater productivity. Smith (1776: 10) goes on to note,

\begin{abstract}
All the improvements in machinery, however, have by no means been the invention of those who had occasion to use the machines. Many improvements have been made by the ingenuity of the makers of the machines, when to make them became the business of a peculiar trade; and some by that of those who are called philosophers or men of speculation, whose trade it is not to do any thing, but to observe every thing; and who, upon that account, are often capable of combining together the powers of the most distant and dissimilar objects.
\end{abstract}

Thus, Smith describes an invisible hand that functions not as an equilibrating force, but as a force that leads the economy along a trajectory determined by the innovations of those who are trying to employ their capital to produce the greatest possible value.

This analysis is not meant to suggest that there are fundamental flaws in equilibrium economics. That framework offers substantial insight into the way that market forces work to pull an economy toward an efficient allocation of resources at any particular point in time, following the ideas of Arrow and Debreu (1954). However, as Holcombe (1989) argues, all models make simplifying assumptions in order to focus in on particular features of the real world, and those things that are assumed away, or that are unrealistically depicted for pedagogical purposes, can never be explained by the model, because they are not depicted by the model.

While the equilibrium framework provides substantial insight into the nature of the economic equilibrium toward which an economy is pulled at a particular point in time, it does not show those forces that cause the economy to evolve over time. As Hayek (1945) notes, understanding the properties of an equilibrium at any point in time is a much simpler undertaking than understanding the forces that cause an economy to change over time. As valuable as the insights of equilibrium economics are, they tell only a small part of the story of economic adjustment and can often be misleading if applied to the evolution of economic activity. 


\section{Competitive forces in an economy}

A good place to start to see the implications of Adam Smith's invisible hand is with the economic actors that Smith describes when he discusses the invisible hand: the people who are directing the allocation of resources in an economy. Smith refers to people who are employing their capital to produce as great a value as possible, but the same argument applies to labor and other resources. This section examines how those economic actors actually do employ their resources to maximize their value in a competitive economy.

The contemporary depiction of competitive forces in a market economy is based on Marshall (1890). To depict competitive firms in a competitive market, Marshall introduces the device of the representative firm, and assumes that every firm in the industry produces a homogeneous product and that each firm is small enough relative to the entire industry that it has no influence on the market price. This same general framework carries through Hicks (1939) and Samuelson (1947) in a general equilibrium setting, and remains at the foundation of mainstream economics into the twenty-first century. Within this framework, competition forces firms to produce at minimum average total cost by choosing the optimal mix of inputs, and using them as efficiently as possible. Firms within this model of competition can do no better-in the long run-than just to earn a normal rate of profit. In the short run, however, firms may be able to earn transitory profits, as Kirzner (1973) notes, by spotting profit opportunities in markets that are in disequilibrium, and acting on them. Entrepreneurial action works to equilibrate the market, causing the transitory profit opportunity to disappear.

In this setting of Marshallian competition, the people who run firms are managers, not entrepreneurs, as Boudreaux and Holcombe (1989) note. The sole role of decision-makers in firms is to choose the optimal combination and level of inputs to produce the profitmaximizing level of output, and, following Alchian and Demsetz (1972), to prevent shirking and inefficient resource use so that, given the firm's inputs, the firm produces the maximum possible output. Profit maximization means cost minimization while choosing the profitmaximizing quantity of output. Within this framework, the decision to enter or exit an industry is entrepreneurial, but that decision is exogenous to the firm's decision-making as depicted by the model. The model either depicts an industry in equilibrium, after all entry and exit have occurred, or a model out of equilibrium that will require some entry or exit to produce an equilibrium. While there is an implied entry and exit to maintain equilibrium in the face of changing conditions, the actual decision to enter or exit lies outside of the model.

Within this Marshallian framework, product homogeneity is an assumption of the model that is necessary to aggregate individual firms into a single market. The assumption of a homogeneous output in competitive markets is required to depict the industry's output in a single dimension in a supply and demand framework to reach the Marshallian competitive equilibrium. When looking at real-world competitive behavior, it is important to recognize that product homogeneity in a Marshallian competitive industry is an assumption, not a conclusion. In fact, real-world competitive forces lead producers to differentiate their products, and differentiated products are a feature of real-world competition, the neoclassical model of competition notwithstanding.

This point cannot be overemphasized if one is trying to extend the equilibrium framework of neoclassical economics to understand the market process. People who run firms are constantly looking for ways to differentiate their products in order to attract customers and to be able to raise their prices and profits: that is, in order to employ their capital to create the greatest value. Product differentiation is a competitive strategy, and an integral feature of competitive markets, despite Marshall's assumption of a homogeneous product in competitive markets. This general idea was recognized in the models of imperfectly competitive 且 Springer 
markets by Chamberlin (1933) and Robinson (1933). The models of Chamberlin and Robinson integrate product differentiation into the neoclassical framework, but like Marshall, they also show that in equilibrium, all economic profits are competed away and firms earn only normal profits.

In the imperfectly competitive markets described by Chamberlin and Robinson, there seems to be little incentive to introduce a differentiated product, because it yields the firm the same competitive return that is available in a perfectly competitive market. Not only do firms have little to gain by introducing differentiated products within this framework, any advantage gained by the firm that undertakes the expense of differentiating its products is shared with competing firms. If firm A differentiates its product to make it different from firm B's product, firm A's product is just a differentiated from firm B's as firm B's product is from firm A's. Apparently, firm A is worse off by the expense it undertook to differentiate its product. $^{2}$ This conclusion follows if the differentiated product is just different, as the literature suggests, but it does not follow if the differentiated product is an improvement over existing products. ${ }^{3}$

A major oversight in this line of reasoning is the assumption that differentiated products are just different, not better. In fact, firms gain a competitive advantage by improving their products, not just making them different. The literature frames this issue by arguing that a disadvantage of imperfectly competitive markets is that in equilibrium firms are producing at higher than minimum average total cost, but this may be more than offset by the greater product variety offered to consumers. There is a trade-off between lower cost and greater product variety. This analysis completely misses the larger economic role of product differentiation. Firms are not just trying to make their products different, they are trying to make them better, and more appealing to consumers. Product differentiation is a mechanism that produces economic progress.

As noted above, a product that is just different but not better conveys many of the same benefits to competitors as it does to the differentiating firm, and puts the differentiating firm at a cost disadvantage equal to the cost of differentiating product from others on the market. Introducing a better product gives the firm a real competitive advantage and increases the demand for its products relative to its competitors. Through the creation of improved products, product differentiation is one mechanism by which firms generate economic progress. Product differentiation is an important competitive strategy for firms in competitive markets, the Marshallian assumption of product homogeneity notwithstanding, which leads to increased levels of consumer welfare. The main benefit of product differentiation is not more choice for consumers, although that is a benefit, but rather is the introduction of better products that drive economic progress.

\footnotetext{
2 One might argue that in a competitive industry (as defined by Marshall) with many firms, product differentiation can move the firm from a situation of pure competition into one of monopolistic competition, allowing some transitory profit by creating a less than perfectly elastic demand curve. This would explain how a competitive industry, as depicted by Marshall, could transition into an imperfectly competitive one, as depicted by Chamberlin and Robinson, but the end result is still one in which all firms earn normal profits, and it still appears that in the end the firm that does the best is the one that does not undertake any product differentiation but after the process works itself out finds itself with a product equally differentiated from others because all of its competitors have differentiated their products. Even if some firms have products that are "more differentiated" than others, the long-run result is still normal profits for all firms, whether they are in purely competitive industries or monopolistically competitive industries.

${ }^{3}$ See Shaffer (2005) for a recent example of an analysis of product differentiation that depicts the only advantage of differentiation as the greater variety available to consumers. This is consistent with the treatment of product differentiation in microeconomics textbooks since the models of Chamberlin and Robinson.
} 
This advantage of product differentiation may be difficult to spot if one looks at the real world at any point in time. Consider, for example, all the different characteristics and features of automobiles, often apparently playing to the tastes of consumers, Galbraith (1958) would argue, rather than implementing any genuine improvement in the product. But of course things would appear this way at any point in time, because differentiated characteristics that consumers did not view as improvements would vanish from products, while those that consumers did view as improvements would be adopted by others in the market. At any point in time, quality differences among products would appear to be small, because lowerquality products and features would disappear from the market, being displaced by those with improved quality. Looking again at the automobile market, it is clear that over time all these minor innovations have added up to a substantial improvement in the product. The differences in characteristics between a new automobile and one ten (or twenty or thirty) years old are substantial and obvious. Over time, product differentiation is the engine of economic progress.

Some goods are so differentiated that they may represent a whole new category of goods (Personal computers? Cellular telephones? Digital cameras?). Yet the mechanism behind these innovations is the same. People who run firms look for ways to improve their products to make them more desirable to purchasers. Their primary goal is not to minimize average total cost, although keeping costs in check is always a desirable management goal. It is to create products that give consumers more utility than products from competing sellers.

\section{Equilibrium versus progress}

Thinking about this in a production function framework, where $\mathrm{Q}$ is output and $\mathrm{K}$ and $\mathrm{L}$ are inputs, so $Q=f(K, L)$, the neoclassical theory of the firm has managers choosing the optimal levels of $\mathrm{K}$ and $\mathrm{L}$ to minimize the cost of producing a given output with a given technology and given inputs. The characteristics of the output $\mathrm{Q}$ are given, and $\mathrm{Q}$ is the same for all firms in a competitive industry, and the production function $\mathrm{f}$ is given to the firm's managers. The characteristics of inputs $\mathrm{K}$ and $\mathrm{L}$ are also given, so the manager has a choice only over the quantities of $\mathrm{K}$ and $\mathrm{L}$.

A more entrepreneurial vision of the firm shows that these managerial decisions are a minor part of what decision-makers in firms determine. Most significantly, they are always looking for ways to change the characteristics of $\mathrm{Q}$ to make their output more appealing to consumers. They are also looking for new production methods to cut costs or make it cost-effective to add features to a product that were not economically feasible under older technologies, and they are looking for new inputs that can be more effective in the production process. $\mathrm{K}$ and $\mathrm{L}$ are not homogeneous, and different types of capital goods, and workers with different sets of skills, could be used in a new production process to produce new, better, cheaper products. ${ }^{4}$

If the current production function is $Q=f(K, L)$, entrepreneurs are looking for ways to differentiate their products, to replace Q with Q', they are looking for more cost-effective factors of production $\mathrm{K}^{\prime}$ and $\mathrm{L}$ ', and for improved production processes $\mathrm{g}$ to replace the

\footnotetext{
${ }^{4}$ The literature almost always assumes that "improvements" imply higher qualities of inputs: better capital equipment and increased human capital. However, much progress can be attributed to adopting production processes that use lower-quality inputs. For example, if a firm can simplify production processes so that workers with lower skills can be used, it can save on labor costs. Similarly, simpler and less expensive capital equipment can also lower costs.
} 
old process $\mathrm{f}$, to advance from $\mathrm{Q}=\mathrm{f}(\mathrm{K}, \mathrm{L})$ to $\mathrm{Q}^{\prime}=\mathrm{g}\left(\mathrm{K}^{\prime}, \mathrm{L}^{\prime}\right)$. In the process, the nature of the economy's output not only changes, but improves. Entrepreneurship is the engine of economic progress, and product differentiation is a mechanism by which entrepreneurs implement progress. While there are forces that equilibrate the economy, the forces of competition in a market economy lead not to an equilibrium, but to continual economic progress along a trajectory determined by the innovations introduced by entrepreneurs.

As Schumpeter (1942: 82) says, "Capitalism, then, is by nature a form or method of economic change and not only never is, but never can be stationary. ... The fundamental impulse that sets and keeps the capitalist engine in motion comes from the new consumers, goods, the new methods of production or transportation, the new markets, the new forms of industrial organization that capitalist enterprise creates." In other words, the essence of a market economy is not that it tends toward some equilibrium allocation of resources, but rather that economic forces lead it along a trajectory that produces a different allocation of resources today than it was yesterday.

\section{Entrepreneurship and equilibrium}

Kirzner (1973) explicitly confronts the relationship between entrepreneurship and equilibrium, arguing that entrepreneurial actions equilibrate the market, in contrast to Schumpeter $(1934,1942)$ who argues that entrepreneurial actions disrupt market equilibria. From Kirzner's point of view, entrepreneurship is an element that adds to the neoclassical depiction of equilibrium. Neoclassical economics explains the properties of economic equilibrium, and Kirzner explains how entrepreneurs pursue profit opportunities to equilibrate an economy that is out of equilibrium. From Schumpeter's point of view, an entrepreneurial economy is different in character from an economy in equilibrium, or approaching equilibrium. Entrepreneurs disrupt existing equilibria by bringing innovations to market, and after the entrepreneurial actions, the economy will never return to its former equilibrium. Schumpeter's entrepreneurs do not create disruptions like supply or demand shifts, they create new markets for new goods and disrupt existing markets for goods that are displaced by innovations. That creative destruction leads the economy in a direction that could not have been anticipated before the innovation was introduced into the economy. ${ }^{5}$

Of course, one can conjecture on the future path of markets, the introduction of new goods, and so forth. A well-known example of such a conjecture is Moore's law, named after Intel Corporation co-founder Gordon Moore, which states that the computing power of microprocessors doubles every 18 months. Based on Moore's law, people have designed computer hardware and software that could not be run on the computers at the time the design began, in anticipation that when the products they were designing reached the market, the power of computers to run them will have increased sufficiently to run their new products. Such activities are similar to Kirzner's (1973) entrepreneurs spotting a profit opportunity, except that the opportunity is not one that exists now, but rather one the entrepreneur anticipates will exist in the future. The more accurate the entrepreneur's forecast is, the closer the economy

\footnotetext{
${ }^{5}$ Baumol (2002) argues that the role of entrepreneurship has been routinized into the normal operation of firms through specialized R\&D activities that find new products and new production processes as a normal part of business operations. Baumol misses the point that while invention (of products and production processes) can be incorporated as a routine operation of business, applying those inventions to take advantage of profit opportunities can never be a routine part of business, because such innovation requires the anticipation of future market direction. Schumpeter (1934) distinguishes between invention and innovation, and while invention can be integrated into business operations through $R \& D$, the innovation of bringing inventions to market in a profitable manner cannot be.
} 
will stay to equilibrium, but the equilibrium is not one that will remain in time, but rather is one that will exist only as a point on a trajectory determined by the entrepreneurial decisions of economic actors.

The trajectory of the economy cannot be in any sense deterministic, because it depends on the many decisions of decentralized economic actors. A different decision by an entrepreneur today changes tomorrow's trajectory, and it should be obvious that because of the uncertainty involved in entrepreneurial decisions, not every entrepreneurial decision will prove correct in hindsight. In keeping with the example of the previous paragraph, entrepreneurs must make decisions today based not only on economic conditions today, but also on what they anticipate economic conditions to be in the future, and those future conditions will be determined in part based on what other entrepreneurs decide today. In such a setting of decentralized decisionmaking in which those decisions determine the future trajectory of the economy, and in which some of those decisions will in hindsight prove incorrect, the economy is led by an invisible hand along a path that can never be deterministic.

Contemporary growth theory is based on the Solow (1956) model in which there is a steady state growth path. Given some initial conditions, the model shows the future path of the economy forever. The growth created by Schumpeter's entrepreneurs is different. When innovations are introduced into the economy, they change the trajectory of the economy in ways that cannot be forecast, and that cannot even be depicted in a Solow-type growth model in which growth shows up only as larger quantities of output. The nature of output changes, and as Arthur (1989) notes, there is a path dependency such that acting on one innovation simultaneously opens up new avenues for innovation as it closes down others. Types of goods, types of production processes, and the nature of technology underlying the production process all are modified in ways that alter the path of economic progress, and that cannot be depicted in models that simply show growth as an increase in aggregate output. Aggregate output does go up, but more significantly, the types of output change and the processes that produce output change.

Neoclassical equilibrium is not very descriptive of this process of economic progress. While it is true that at any particular point in time economic forces are holding the economy close to some equilibrium, it is more significant that economic forces are leading the economy on a non-deterministic path of progress in which new goods and new production processes are continually being introduced. Kirzner's entrepreneurs are pulling the economy toward today's equilibrium while Schumpeter's entrepreneurs are leading the economy away from it. According to Schumpeter (1934: 64), entrepreneurial innovation creates a “... kind of change arising from within the system which so displaces the equilibrium point that the new one cannot be reached from the old one by infinitesimal small steps." This disruption created by Schumpeterian entrepreneurs opens up profit opportunities for Kirznerizan entrepreneurs.

While one would not want to downplay the role of entrepreneurship in equilibrating the economy, its role in generating economic progress is ultimately more significant. As Hayek (1945: 523) notes, "It is, perhaps, worth stressing that economic problems arise always and only in consequence of change. So long as things continue as before, or at least as they were expected to, there arise no new problems requiring a decision, and no need to form a new plan." In the context of neoclassical equilibrium, entrepreneurship serves the equilibrating role of allowing things to continue as before. Schumpeterian entrepreneurs produce the change that gives rise to the necessity of making decisions and forming new plans. Then entrepreneurs make the decisions and form the new plans in response to the earlier changes. Entrepreneurship induces more entrepreneurship, as Holcombe (1998, 2003b) notes.

Entrepreneurship does serve an equilibrating role, as Kirzner (1973) argues, which in the short run keeps resources from being misallocated. Taking a longer time horizon, however, 
entrepreneurship is not holding the economy close to an existing equilibrium, it is defining the path along which economic progress takes place, and moving the economy from the existing equilibrium. It is not a path that is deterministic, even in theory, because innovations introduced into the economy at one point in time affect its future trajectory. While one might talk about an equilibrium trajectory of income or an equilibrium rate of growth, this aggregate depiction of the process makes little sense in the context of the new goods and production processes that are continually being introduced into the economy. People do not produce income, or some generic "output," they produce specific goods and services, and the growth path of the economy is not determined in the aggregate, but rather by the individual decisions of economic actors to do things differently in the future from the way they have done things in the past. Within the right institutional framework, all of these differences add up to economic growth, but the aggregate phenomenon cannot be understood independently of the individual decisions that produce it.

Despite Kirzner's correct argument that entrepreneurship serves an equilibrating role, the role of entrepreneurship in the economy is not to lead it toward an equilibrium, but rather to lead it away from the existing equilibrium.

\section{Market adjustment}

As Kirzner (1973) describes entrepreneurial actions, it appears as if there is a stock of profit opportunities that lie undiscovered. One could envision, conceptually anyway, that eventually all of the existing profit opportunities could be discovered and no profit opportunities would remain. This is because, as Holcombe (2003b) notes, Kirzner explains how entrepreneurs act on profit opportunities but he does not explain where they come from. In fact, entrepreneurial actions do not use up profit opportunities, they create additional profit opportunities, as described by Holcombe (1998, 2003b). An implication of the observation that entrepreneurship does not use up profit opportunities, but rather creates them, is that the more entrepreneurial an economy is, the faster it tends to move away from an existing static equilibrium as conceived by neoclassical theory.

At some point, the language of describing the nexus of exchanges toward which an economy is gravitating as an equilibrium obscures more than it illuminates. If that equilibrium is continually changing and is never actually reached, it might better be described as a trajectory, or a time-path, than an equilibrium. The issue is further obfuscated by the notion, described in Solow (1956), of an equilibrium growth path. In contrast to Solow's deterministic growth path (determined once initial conditions are specified), the actual economy follows a pathdependent trajectory in which choices made at one point in time alter the future course of economic progress. The invisible hand is not holding the economy near an equilibrium, it is leading the economy on a path of economic progress that is defined by —and altered by - the entrepreneurial activities of its participants.

There are elements in individual entrepreneurial acts that in some sense appear more Schumpeterian, and in another sense appear more Kirznerian, but those elements find their common origin in the behavior described by Adam Smith, who says that individuals are attempting to employ their capital to create the greatest value. When entrepreneurs spring innovations on the market, initiating creative destruction as new enterprises are formed but old ones fall by the wayside, the actions of entrepreneurs create the economic progress that has continued steadily since the beginning of the industrial revolution. The disruptive effects of these Schumpeterian entrepreneurs leave some resources employed inefficiently, or in some cases not employed at all. Thus, a profit opportunity is created for Kirznerian entrepreneurs 
to act on such markets in disequilibrium, reallocating resources to more efficient uses. But these Kirznerian entrepreneurs are not returning the economy to an equilibrium, they are keeping resources efficiently employed as the economy moves along a continually changing path of economic progress.

\section{Can the invisible hand lose its grasp?}

Taking an approach to economics focused on equilibrium, it would seem that the question posed in the heading of this section would be answered by addressing the stability of general equilibrium. Yet in an evolving and entrepreneurial economy the issue is not whether an equilibrium is stable, but whether economic forces in an economy are robust enough to allow economic agents to keep pace with changing economic conditions. Schumpeterian entrepreneurs are continually disrupting the established order, and Kirznerian entrepreneurs are continually trying to adjust the allocation of resources to reflect the newly-created conditions. The question is whether the Kirznerian entrepreneurs can keep up with the Schumpeterian entrepreneurs! Schumpeter (1939) frames the issue in this way-minus the reference to Kirzner of course-and attributes business cycles to the disruptions caused by entrepreneurial innovations.

In modern macroeconomic models it is fashionable to depict such disruptions as "shocks" that suddenly disequilibrate the economy. In reality, such disruptions tend to be introduced gradually into an economy, allowing Kirznerian entrepreneurs to adjust their plans to keep resources allocated efficiently as the disruption works its way through the economy. As automobiles displaced horses and wagons - and eventually streetcars and locomotivesentrepreneurs could see the trends and reallocate resources to accommodate them. Autos did not displace horse-drawn vehicles overnight, but rather over a period of decades, and although some industries shrank or disappeared as others grew, market forces were able to marshal the specific knowledge of time and place that each economic actor possessed to keep resources allocated efficiently through the transition. People in some industries could see profit opportunities, encouraging them to expand and attracting new entrants, while those in other industries could see profits shrinking or disappearing, signaling them to reallocate resources. A similar story could be told about computers replacing typewriters and cell phones replacing wired phone services.

A better example of a shock would be something like the 1973 OPEC oil embargo, but even there, the shock registered itself as a price change that induced changes in behavior that occurred over a period of time. Higher gasoline expenditures meant lower expenditures on other goods, but the effect was spread throughout the economy. Meanwhile, although there was an increase in the demand for more fuel-efficient automobiles and a decline in the demand for gas guzzlers, that impact was also gradual as newer more fuel-efficient cars replaced the existing fleet. General Motors did not suddenly go out of business, displaced by Toyota, a manufacturer of more fuel-efficient automobiles. Rather, market signals produced a shift in the product mix of all automobile manufacturers. OPEC is a government-backed cartel, of course, but even in this case, a shock to the market opened entrepreneurial opportunities in some areas at the same time that it disrupted other markets. The question is whether Kirznerian entrepreneurs can act quickly enough to maintain an efficient allocation of resources as the economy adjusts along its continually-changing trajectory.

Hayek (1945) argues that the market system provides an effective mechanism for coordinating the decentralized economic knowledge held by everyone in the economy, and if markets are allowed to function without impediment, resources will be allocated efficiently. 
This does not suggest that disruptions will cause no economic dislocations. On the contrary, when people have made investments in anticipation of one set of economic conditions and when the future brings a different set of conditions, some readjustment will be necessary, and readjustment will take time and will not be costless. That readjustment is initiated by Kirznerian entrepreneurship.

Impediments to market exchange will slow-or perhaps even stop-the readjustment process. As Smith (1776: 17) noted, the division of labor is limited by the extent of the market, and some impediments to exchange will be transaction costs such as transportation costs, communication costs, or informational barriers. Entrepreneurs have an incentive to lower those barriers, and indeed, much entrepreneurship has been devoted to lowering these costs and increasing the extent of the market, which facilitates exchange and the division of labor. Other impediments to exchange will be induced by government policies.

Regulations fix into place a particular response to a particular problem, and even if the response is in some sense optimal when it is initiated, it limits the ways in which markets can respond to future problems. For example, U.S. government regulations imposing automobile safety standards prevent the importation of some fuel-efficient automobiles used in other parts of the world, so safety regulations have the unintentional consequence of limiting entrepreneurial responses to changes in fuel costs. Government monetary policies can cause even greater impediments to adjustment, as Garrison (2001) notes, updating Hayek's business cycle theory. In this case, the price signals necessary for the market to coordinate people's economic activities are distorted, sending noisy or even incorrect signals to potential entrepreneurs. The ability of Kirznerian entrepreneurship to adjust to the disruption is compromised.

A robust economy is one that allows Kirznerian entrepreneurship — that adjusts people's economic activities to the effects of market disruptions - to act rapidly to offset those disruptions. If disruptions create dislocations more rapidly than Kirznerian entrepreneurs can adjust to them, the economy will not be robust, resources will be inefficiently allocated, and the invisible hand can lose its grasp. This might happen either from an increase in disruptionsor one very large disruption - or from impediments to the entrepreneurial actions that adjust to disruptions.

When automobiles displaced horses and wagons early in the twentieth century (in the United States), new industries were created as others were destroyed (or severely weakened because of declining demand), but no major economic problems were created as a result because as resources left horse-related industries, entrepreneurs were able to re-employ them in other industries, creating an increasing standard of living as the adjustment occurred. In contrast, as improvements in agricultural productivity reduced the resource requirements for food production, government agricultural policies discouraged people from leaving the industry, creating inefficiencies and ever more elaborate government programs to mitigate the effects of earlier government programs. Similarly, government interference in the economy during the 1930s - in monetary policy, the banking sector, tariff policy, regulatory policies, and through transfer programs-reduced entrepreneurial incentives and altered the marketdriven signals of the price system so that entrepreneurial adjustment was unable to keep pace with disruptions in the economy. The invisible hand was losing its grasp.

\section{Conclusion}

Adam Smith did not describe the invisible hand as a mechanism that holds the economy near an equilibrium, or pulls a disequilibrated economy toward equilibrium. Rather, he depicted 
an invisible hand that leads the economy on a trajectory of economic progress determined by the entrepreneurial actions of producers. In the passage that refers to the invisible hand, Smith says that owners of capital want to employ their capital to create the greatest value, and elsewhere in The Wealth of Nations Smith describes how all producers in an economy, from entrepreneurs and firm owners down to laborers and manufacturing workers, innovate by finding "easier and readier" methods of performing their work. Thus, the invisible hand does not hold an economy close to equilibrium, but leads it on a path of economic progress.

As Hayek (1945) notes, economic decision-making is relatively straightforward in a steady-state environment. Challenges arise when economic actors must react to change, and the market system coordinates the decentralized economic activities of everyone in response to continually changing circumstances. Because people must make decisions today that affect their economic activities in the future, it is unlikely that everybody's plans will be mutually consistent, but the market system helps to coordinate people's plans, and market prices economically convey information to people about the economic activities of others. Kirzner (1973) describes how, when circumstances change, entrepreneurs act on profit opportunities to equilibrate the economy, but this equilibrium framework is too static to describe the broader role of entrepreneurship. Entrepreneurs continually disrupt current patterns of production and consumption, requiring a reallocation of resources from activities that are no longer profitable while at the same time creating new profit opportunities elsewhere. Kirznerian entrepreneurs act on these profit opportunities, enhancing the efficiency of resource allocation as the economy continues on a trajectory largely determined by the decisions of entrepreneurs in earlier time periods. In a robust economy, entrepreneurs are able to adapt to disruptions as rapidly as they occur, maintaining an efficient use of resources. If the pace of disruptions overwhelms the ability of entrepreneurs to adjust, dislocations can cause resources to be inefficiently employed — or to remain unemployed — and market prices in such a disequilibrium situation become less reliable as signals for efficient and profitable resource allocation.

The question posed in the title of this paper might at first appear to be an irrelevant question about an abstraction of Adam Smith's, but this discussion suggests that the answer to that question implies a great deal about the nature of the economy. Smith did not describe an economy that was held in place by an invisible hand, but rather one that was led by an invisible hand along a trajectory determined by individuals making best use of their specific knowledge of time and place. This decentralized knowledge is coordinated by a market system that gives people the incentive to respond to the disruptions introduced by some to reallocate resources to keep them employed in their highest-valued uses. This is equilibrating in the sense that it reallocates resources so that they are more efficiently used, but ultimately the notion of equilibrium falls short because there is not some unique stable allocation of resources toward which the economy is headed, Arrow and Debreu (1954) notwithstanding; rather, there is a continually changing trajectory along which the economy is moving, its path constantly altered by the entrepreneurial decisions of the economy's participants. The invisible hand leads the economy along this trajectory, and economic incentives guide individual behavior to keep overall economic activity close to this trajectory. Those incentives that maintain the economy on a trajectory of economic progress are the invisible hand.

\section{References}

Alchian, A. A., and H. Demsetz (1972). "Production, Information Costs, and Economic Organization.” American Economic Review 62: 777-795.

Arrow, K. J., and G. Debreu (1954). "The Existence of an Equilibrium for a Competitive Economy.” Econometrica 22: 265-290. 
Arthur, W. B. (1989). "Competing Technologies, Increasing Returns, and Lock-In by Historical Events." Economic Journal 99: 116-131.

Baumol, W. J. (2002). "The Free Market Innovation Machine: Analyzing the Growth Miracle of Capitalism." Princeton, NJ: Princeton University Press.

Boudreaux, D. J. and R. G. Holcombe (1989). “The Coasian and Knightian Theories of the Firm.” Managerial and Decision Economics 10: 147-154.

Chamberlin, E. (1933). "The Theory of Monopolistic Competition.” Cambridge, MA: Harvard University Press.

Galbraith, J. K. (1958). “The Affluent Society.” Boston: Houghton Mifflin.

Garrison, R. W. (2001). “Time and Money: The Macroeconomics of Capital Structure.” London and New York: Routledge.

Hayek, F. A. (1945). "The Use of Knowledge in Society,” American Economic Review 35: 519-530.

Hicks, J. R. (1939). "Value and Capital: An Inquiry Into Some Fundamental Principles of Economic Theory." Oxford: Clarendon Press.

Holcombe, R. G. (1989). "Economic Models and Methodology.” New York: Greenwood.

Holcombe, R. G. (1998). "Entrepreneurship and Economic Growth.” Quarterly Journal of Austrian Economics 1: $45-62$.

Holcombe, R. G. (1999). “Equilibrium Versus the Invisible Hand.” Review of Austrian Economics 12: $227-243$.

Holcombe, R. G. (2003a). "Progress and Entrepreneurship.” Quarterly Journal of Austrian Economics 6: 3-26.

Holcombe, R. G. (2003b). “The Origins of Entrepreneurial Opportunities.” Review of Austrian Economics 16: 25-43.

Keynes, J. M. (1936). “The General Theory of Employment, Interest, and Money.” New York: Harcourt, Brace \& Company.

Kirzner, I. M. (1973). “Competition and Entrepreneurship.” Chicago: University of Chicago Press.

Kohn, M. (2004). "Value and Exchange." Cato Journal 24: 303-339.

Marshall, A. (1890). "Principles of Economics." London: Macmillan.

Robinson, J. (1933). "The Economics of Imperfect Competition.” London: Macmillan.

Samuelson, P. A. (1947). "Foundations of Economic Analysis.” Cambridge: Harvard University Press.

Schumpeter, J. A. (1934). "The Theory of Economic Development.” Cambridge: Harvard University Press.

Schumpeter, J. A. (1939). "Business Cycles: A Theoretical, Historical, and Statistical Analysis of the Capitalist Process.” New York: McGraw-Hill.

Schumpeter, J. A. (1942). “Capitalism, Socialism, and Democracy.” New York: Harper.

Shaffer, G. (2005). "Slotting Allowances and Optimal Product Variety" Advances in Economic Analysis and Policy 5: www.bepress.com/bejeap/advances/vol5/iss1/art3/

Smith, A. [1776] (1937). “An Inquiry Into the Nature and Causes of the Wealth of Nations.” New York: Modern Library.

Solow, R. M. (1956). "A Contribution to the Theory of Economic Growth.” Quarterly Journal of Economics 70: 65-94. 